\title{
Effect of supplementation of grazing dairy ewes with a cereal concentrate on animal performance and milk fatty acid profile ${ }^{1}$
}

\author{
P. Gómez-Cortés, ${ }^{*}$ P. Frutos, † A. R. Mantecón, † M. Juárez, ${ }^{*} M$. A. de la Fuente, ${ }^{* 2}$ and G. Hervás† \\ *Instituto del Frío (Consejo Superior de Investigaciones Científicas, CSIC), José Antonio Novais 10, Ciudad Universitaria s/n, 28040 Madrid, \\ Spain \\ †Instituto de Ganadería de Montaña (CSIC-Universidad de León), Finca Marzanas s/n, 24346 Grulleros, León, Spain
}

\begin{abstract}
This work was conducted to investigate the effect of supplementing grazing ewes on pasture with a cereal concentrate on the milk fatty acid (FA) profile. Ninety Assaf ewes in mid lactation were distributed in 9 lots of 10 animals each and allocated to 3 feeding regimens: 1) pasture - ewes were only allowed to graze pasture (an irrigated sward of Lolium perenne, Trifolium pratense, and Dactylis glomerata); 2) PS-grazing ewes were supplemented with oat grain $(700 \mathrm{~g} /$ animal and day); and 3) TMR - ewes were fed ad libitum a total mixed ration (TMR; 80:20 concentrate/forage ratio). Milk yield and composition were recorded for 5 wk. The highest milk yield was observed in ewes receiving the TMR and the lowest in grazing ewes supplemented with oat grain. Productions of milk fat, protein, and total solids showed the lowest values in treatment PS. The atherogenicity index, which comprises C12:0, C14:0, and C16:0, in PS milk fat was no different from that observed in milk from animals on pasture (1.53 for pasture, 1.54 for PS, and 3.22 for TMR). Oat grain supplementation generated higher amounts of C18:0 and cis-9 C18:1 in milk fat than the pasture-only diet, but significantly decreased the levels of $\alpha$-linolenic acid and most of intermediates of the process of biohydrogenation of this FA. Cis-9 trans-11 C18:2 and trans-11 C18:1, its precursor for endogenous synthesis in the mammary gland, were lower in PS (0.58 and $1.59 \mathrm{~g} / 100$ $\mathrm{g}$ of total FA) than in TMR $(0.72$ and $1.92 \mathrm{~g} / 100 \mathrm{~g}$ of total FA) and very different from the results observed in grazing ewes receiving no supplement (1.21 and 3.88 $\mathrm{g} / 100 \mathrm{~g}$ of total FA). Furthermore, the lowest levels of trans-10 C18:1 and trans-10 cis-12 C18:2 were detected in the milk fat of ewes fed pasture. It is concluded that,
\end{abstract}

\footnotetext{
Received January 17, 2009.

Accepted February 27, 2009.

${ }^{1}$ Presented in part at the 12 th Seminar of the FAO-CIHEAM (Food and Agriculture Organization of the United Nations - Le Centre International de Hautes Etudes Agronomiques Méditerranéennes) SubNetwork on Sheep and Goat Nutrition: Nutritional and foraging ecology of sheep and goats; October 11-13, 2007, Thessalonika, Greece.

${ }^{2}$ Corresponding author: mafl@if.csic.es
}

when pasture quality and availability do not limit dairy production, supplementation of grazing ewes with oat grain compromised the milk FA profile without any significant positive effect on milk production.

Key words: cereal supplement, conjugated linoleic acid, pasture, sheep

\section{INTRODUCTION}

Milk fat content and fatty acid (FA) composition can be significantly altered in dairy ruminants through different feeding strategies, with the consequent possibility of responding to market forces and human health recommendations. Current research is oriented toward reducing the amount of saturated FA (SFA) and increasing beneficial polyunsaturated FA (PUFA), particularly conjugated linoleic acid (CLA) and n-3 FA. Rumenic acid (RA, cis-9 trans-11 C18:2), the most important CLA isomer from a nutritional point of view, is produced as an intermediate of ruminal biohydrogenation of linoleic acid (C18:2) and by endogenous synthesis from vaccenic acid (VA, trans-11 C18:1).

Pasture-based systems, commonly used in Mediterranean countries for sheep production, result in milks rich in fat because of the high content of fiber in the diets, flavor compounds, and micronutrients favorable to human nutrition and health (Cabiddu et al., 2005; Morand-Fehr et al., 2007).

Pastures are known to be rich in PUFA, whose biohydrogenation in the rumen results in the production of several intermediates such as VA (Addis et al., 2005). Several studies have examined feeding strategies to enhance the nutritional FA profile of ewe's milk and concluded that pasture-based diets seemed to favor that aim (Addis et al., 2005; Cabiddu et al., 2005; Tsiplakou et al., 2006). Other studies have reported that lactating ruminants fed conserved forages or cereal-based concentrates produce milk fat with lower concentrations of CLA and PUFA compared with animals fed on pastures (Pulina et al., 2006). However, in many Mediterranean rangelands, when the pasture is overgrazed or of poor quality (e.g., in dry periods), the diet may become very poor and inadequate for milk 
production. Under those circumstances, grazing dairy ewes are often supplemented with concentrates, which may change the rumen biohydrogenation pathways of pasture FA and negatively affect their milk FA profile.

Little information is available on the effects of concentrates added to pasture-based diets on FA composition in milk from small ruminants (Morand-Fehr et al., 2007). We therefore carried out this study to investigate the effect on milk yield and composition of supplementing ewes on pasture with a cereal concentrate, paying particular attention to the FA profile and CLA isomers. Oat grain, which is traditionally used to supplement grazing small ruminants because of its ability to keep the rumen environment more stable than other cereals (Orskov et al., 1974), was chosen as the cereal concentrate. Results were compared not only with those obtained from grazing ewes without supplementation but also with those from ewes managed under an intensive system and fed a TMR.

\section{MATERIALS AND METHODS}

\section{Animals, Experimental Design, and Milking Management}

Ninety Assaf ewes in mid lactation (at wk 6 postpartum at the beginning of the experiment) were used, distributed in 9 lots of 10 each, balanced for milk yield, DIM, and BW, and allocated at random to 3 feeding regimens (3 lots per treatment). The feeding regimens were as follows: 1) pasture - ewes were only allowed to graze pasture (an irrigated sward of Lolium perenne, Trifolium pratense, and Dactylis glomerata) during May and June on a plot of approximately $10,000 \mathrm{~m}^{2} ; 2$ ) PSgrazing ewes (confined to a plot of approximately 7,000 $\left.\mathrm{m}^{2}\right)$ were supplemented with oat grain $(700 \mathrm{~g} /$ animal and day); and 3) TMR - ewes were fed ad libitum a TMR (80:20 concentrate:forage ratio).

The ingredients of the TMR and the chemical composition of the experimental diets are given in Table 1. Clean water and vitamin-mineral blocks were always freely available for all animals. The oat supplement (PS treatment) was offered immediately after morning milking and ewes consumed it completely within about 15 min. The TMR diet (TMR treatment) was freshly offered ad libitum, every day at about 0900 and 1900 h.

Ewes were milked at 0830 and $1830 \mathrm{~h}$ in a $1 \times 10$ stall milking parlor (DeLaval, Madrid, Spain). The experiment lasted for a total of $5 \mathrm{wk}$ and was carried out in accordance with Spanish Royal Decree 1201/2005 for the protection of animals used for experimental purposes.

\section{Measurements, Sample Collection, and Chemical Analysis}

The sward surface height was measured weekly using an HFRO (Hill Farming Research Organisation, Penicuik, UK) swardstick (Barthram, 1986), taking 100 measurements at random per plot. Furthermore, grass availability was measured once a week by cutting 4 squares $\left(0.25 \mathrm{~m}^{2} /\right.$ square $)$ of pasture to ground level. Samples of pasture, oat grain, and TMR were collected weekly, stored at $-30^{\circ} \mathrm{C}$, and then freeze-dried for chemical composition analysis.

Feed samples (pasture, oat grain, and TMR) were analyzed for DM (ISO, 1999a; ISO 6496), ash (ISO, 2002a; ISO 5984), CP (ISO, 2005; 5983-2), and ether extract (AOCS, 2008; Official Procedure Am 5-04). Neutral- and acid-detergent fiber were determined by the methods described by Mertens (2002) and AOAC (2006; method 973.18), respectively, using an Ankom $^{2000}$ Fiber Analyzer (Ankom Technology Corp., Macedon, NY); NDF was assayed with sodium sulfite and $\alpha$-amylase and expressed with residual ash (the latter also for ADF).

Individual milk yield was recorded on $1 \mathrm{~d} /$ week $(\mathrm{d} 0$, $7,14,21,28$, and 35) at morning and evening milkings. Milk samples for the determination of fat, protein, and TS concentrations were also collected $1 \mathrm{~d}$ /week from each animal. Fat, protein, and TS concentrations were determined (ISO, 1999b; 9622) in samples treated with natamycin.

Untreated samples of milk from each experimental lot, composited according to individual milk yield, were stored at $-20^{\circ} \mathrm{C}$ until fat extraction for FA analysis. Total milk fat was extracted following the procedure of Luna et al. (2005a). Fatty acids were esterified to methyl esters (FAME) using $\mathrm{KOH} / \mathrm{MeOH}$ at room temperature (ISO, 2002b; 15884). Fatty acid profile was then determined using a gas chromatograph (Agilent 6890 N Network System, Palo Alto, CA) equipped with an autoinjector, a 100-m column (CP-Sil 88 fused-silica capillary column), and a flame-ionization detector in the conditions described by Gómez-Cortés et al. (2008).

Quantification of individual FAME was made by reference to a milk fat with a known composition (CRM 164; European Community Bureau of Reference, Brussels, Belgium). Individual CLA isomers were identified by comparison to standard mixtures distributed by Nu-Chek Prep. (Elysian, MN); GLC-461 from Nu-Chek was also used to identify other FA. The cis-9 trans-11 cis-15 C18:3 standard was a generous gift from Paul Angers (Université Laval, Montreal, Canada).

In addition, the CLA isomer profiles corresponding to the samples at 0,2 , and 5 wh were determined by 
Table 1. Ingredients, chemical composition, and fatty acid profile of the pasture, oat grain, and TMR

\begin{tabular}{|c|c|c|c|}
\hline Item & Pasture & Oat grain & TMR \\
\hline \multicolumn{4}{|l|}{ Ingredients, $\mathrm{g} / \mathrm{kg}$} \\
\hline Dehydrated alfalfa hay (particle size $>4 \mathrm{~cm}$ ) & - & - & 200 \\
\hline Whole corn grain & - & - & 250 \\
\hline Soybean meal & - & - & 200 \\
\hline Whole barley grain & - & - & 150 \\
\hline Beet pulp & - & - & 90 \\
\hline Molasses & - & - & 65 \\
\hline Salts ${ }^{1}$ & - & - & 40 \\
\hline Minerals and vitamins ${ }^{2}$ & - & - & 5 \\
\hline \multicolumn{4}{|l|}{ Chemical composition, $\mathrm{g} / \mathrm{kg}$ of DM } \\
\hline $\mathrm{DM}$ & 259 & 892 & 875 \\
\hline $\mathrm{OM}$ & 907 & 976 & 901 \\
\hline $\mathrm{CP}$ & 168 & 111 & 189 \\
\hline NDF & 476 & 426 & 242 \\
\hline $\mathrm{ADF}$ & 256 & 176 & 127 \\
\hline Ether extract & 25 & 62 & 21 \\
\hline \multicolumn{4}{|l|}{ Fatty acid profile, $\%$ of total fatty acid } \\
\hline $\mathrm{C} 16: 0$ & 18.3 & 22.4 & 17.3 \\
\hline C18:0 & 2.2 & 2.3 & 3.0 \\
\hline C18:1 & 5.7 & 47.2 & 26.2 \\
\hline C18:2 & 21.0 & 24.6 & 45.5 \\
\hline $\mathrm{C} 18: 3$ & 33.8 & 1.6 & 3.8 \\
\hline $\mathrm{C} 20: 0$ & 0.5 & 0.2 & 0.4 \\
\hline C20:2 & 5.3 & 0.4 & 1.1 \\
\hline C22:0 & 0.7 & 0.3 & 0.4 \\
\hline $\mathrm{C} 22: 2$ & 8.4 & 0.4 & 1.9 \\
\hline
\end{tabular}

${ }^{1}$ Containing $\mathrm{NaHCO}_{3}(37.5 \%), \mathrm{CaCO}_{3}(35 \%), \mathrm{Ca}_{2} \mathrm{HPO}_{4}(15 \%)$, and mine salt (12.5\%; a dietary mineral obtained from a mine and primarily composed of sodium chloride).

${ }^{2}$ INA OV1 (Evialis, Madrid, Spain).

silver ion HPLC $\left(\mathrm{Ag}^{+}\right.$-HPLC). Separations were carried out on a Shimadzu SPE-MA10AVP (Shimadzu, Kyoto, Japan $)$ with 3 columns in series $(250 \mathrm{~mm} \times 4.6 \mathrm{~mm}$ i.d. stainless steel; 5 - $\mu \mathrm{m}$ particle size; Varian, Middelburgh, the Netherlands). A fresh mixture of acetonitrile (0.1\%) and diethyl ether $(0.5 \%)$ in hexane was used to elute the CLA isomers at a flow rate of $1 \mathrm{~mL} / \mathrm{min}$. Because a reliable internal standard for CLA is not yet available, data were related to $\mathrm{GC}$ results. The sum $\mathrm{Ag}^{+}$-HPLC areas for 7-9, 8-10, and 9-11 positional isomers ( $\mathrm{cis}$ trans plus trans-cis) were used for comparison with the peak area of these 3 isomers from the gas chromatogram. The amounts of the other CLA isomers were calculated from their $\mathrm{Ag}^{+}$-HPLC areas relative to the area of the main isomer $9-11$, as described by Collomb et al. (2004).

\section{Statistical Analyses}

Data on milk yield and composition as well as FA composition and CLA profile were analyzed by repeated measurement analysis using the MIXED procedure of SAS (version 9.1, SAS Institute Inc., Cary, NC) and assuming a compound symmetric structure on the basis of Schwarz's Bayesian information model fit criteria. The statistical model included the fixed effects of diet
(D), experimental week $(\mathrm{W})$, their interaction $(\mathrm{D} \times \mathrm{W})$, and the initial record measured at wk 0 (covariate). For all data collected individually (milk yield and composition) or per lot (FA composition and CLA profile), the lot nested within diet was considered as a random effect and used to contrast the effect of the diet. Lots (replicates) were nested within feeding regimens and used as the error term to contrast the diet effect. Regression analyses were performed using the REG procedure of SAS version 9.1. Significance was considered at $P<$ 0.05 , and differences of $P>0.05$ to $P<0.10$ were discussed as trends. Least squares means (adjusted for the covariance) are reported throughout.

\section{RESULTS AND DISCUSSION}

\section{Diet Composition and Grass Availability}

Chemical composition and FA contents of feeds (pasture, oat grain, and TMR) are presented in Table 1. As expected, the TMR diet had the highest CP content, followed by the pasture, with the opposite results observed for the cell wall components (NDF and ADF). All feeds, particularly the TMR, were good sources of linoleic acid (C18:2) and only the pasture was rich in $\alpha$-linolenic acid (C18:3), although the level (34\% of to- 
Table 2. Milk production (g/d) and composition (\%) for ewes fed pasture, pasture plus oat grain (PS), and a TMR

\begin{tabular}{|c|c|c|c|c|c|c|c|}
\hline \multirow[b]{2}{*}{ Item } & \multicolumn{3}{|c|}{ Diet } & \multirow[b]{2}{*}{$\mathrm{SED}^{1}$} & \multicolumn{3}{|c|}{$P$-value ${ }^{2}$} \\
\hline & Pasture & PS & TMR & & D & W & $\mathrm{D} \times \mathrm{W}$ \\
\hline \multicolumn{8}{|c|}{ Production } \\
\hline Milk & $2,300^{\mathrm{b}}$ & $1,960^{\mathrm{c}}$ & $2,850^{\mathrm{a}}$ & 92.0 & $<0.01$ & $<0.01$ & 0.11 \\
\hline Fat & $116^{\mathrm{b}}$ & $111^{\mathrm{b}}$ & $125^{\mathrm{a}}$ & 3.2 & 0.01 & $<0.01$ & 0.28 \\
\hline Protein & $113^{\mathrm{b}}$ & $90^{\mathrm{c}}$ & $136^{\mathrm{a}}$ & 5.3 & $<0.01$ & $<0.01$ & 0.13 \\
\hline TS & $368^{\mathrm{b}}$ & $318^{\mathrm{c}}$ & $434^{\mathrm{a}}$ & 9.6 & $<0.01$ & $<0.01$ & 0.11 \\
\hline \multicolumn{8}{|c|}{ Composition } \\
\hline Fat & $5.1^{\mathrm{b}}$ & $5.5^{\mathrm{a}}$ & $4.5^{\mathrm{c}}$ & 0.12 & $<0.01$ & 0.03 & 0.20 \\
\hline Protein & $4.9^{\mathrm{a}}$ & $4.6^{\mathrm{b}}$ & $4.8^{\mathrm{a}}$ & 0.04 & $<0.01$ & $<0.01$ & 0.42 \\
\hline TS & $16.0^{\mathrm{a}}$ & $16.2^{\mathrm{a}}$ & $15.3^{\mathrm{b}}$ & 0.12 & $<0.01$ & $<0.01$ & 0.48 \\
\hline
\end{tabular}

${ }^{\mathrm{a}-\mathrm{c}}$ Means within a row with different superscripts differ significantly.

${ }^{1} \mathrm{SED}=$ standard error of the difference.

${ }^{2}$ Probability of significant effects due to treatment (D), experimental week (W), and their interaction $(\mathrm{D} \times$ W).

tal FA) was lower than expected based on the literature (e.g., Cabiddu et al., 2005; Mel'uchová et al., 2008).

The sward surface height ranged from 7.5 to $31.5 \mathrm{~cm}$, and the estimated grass availability during the experimental period was, on average, $9.5 \pm 0.46 \mathrm{t}$ of $\mathrm{DM} /$ ha. These values suggest that herbage mass on offer was high and did not limit the intake of mid-lactation grazing sheep (Cabiddu et al., 2006).

\section{Animal Performance}

Table 2 shows the milk yield and composition for ewes on the pasture, PS, and TMR treatments. The highest milk yield was observed in ewes receiving the TMR and the lowest in grazing ewes supplemented with oat grain $(P<0.01)$. The use of feeding systems combining pasture with additional feed supplements is a common practice in many dairy sheep farming systems in Mediterranean countries, where the diet is based on pasture, which is heavily influenced by environmental factors (Molle et al., 2008). Theoretically, the main objective of grazing supplementation is to increase total DM and energy intake to increase milk production (Bargo et al., 2003). However, in animals grazing high-quality pastures, the supply of concentrates often results in high substitution rates, especially when the sward height is high (Bocquier et al., 1988; Bargo et al., 2003). Therefore, the total increase in DM and energy intake and the milk response can be small (Molle et al., 2008) or even negative if the substitution rate exceeds $100 \%$. Molle et al. (1997) observed this effect associated with a decrease in milk response as the sward height increased and lactation progressed. In agreement with milk yield results, production of milk fat, protein, and TS showed the lowest values in treatment PS, which might also be related to a possible lower protein intake (see Table 1) together with interactions among several nutritional factors (such as the source of dietary NDF and NFC, and the energy concentration of the diets; Pulina et al., 2006). Ewes on the PS treatment showed the lowest milk protein concentration $(P<0.01)$, which was in agreement with its higher milk fat concentration $(P<0.05$; Lock et al., 2006).

Values of milk, milk protein, and milk fat production decreased with time $(P<0.01)$. On the other hand, the milk fat, protein, and TS percentages remained relatively steady throughout the study although the statistical analysis shows a significant effect of the experimental week $(P<0.05)$, probably because of the low variability observed.

\section{Milk Fatty Acid Composition}

As shown in Table 3, pasture intake decreased the linoleic acid and increased the $\alpha$-linolenic acid content of milk fat, in agreement with the FA composition of the diets. Enhanced concentrations of C18:0 in milk from ewes fed pasture (pasture or PS treatments; Table 4) must have been due to a more complete hydrogenation of PUFA into C18:0. Compared with the TMR treatment, the rumen environment would be less altered by a diet based on pasture, so microbiota could more easily convert VA into stearic acid. Subsequently, the increase in C18:0 in the rumen would favor the increase of oleic acid (cis-9 C18:1) in milk fat, because this FA is endogenously synthesized from C18:0 via $\Delta^{9}$-desaturase in the mammary gland. Increased stearic and oleic acids levels, together with decreases in C6:0 to C16:0 are usually observed in milk fat from grazing cows and goats compared with animals fed TMR diets (Chilliard et al., 2007). This new FA profile could be because of a dilution effect of dietary FA or a potential 
inhibition of such PUFA on the de novo lipogenesis in the mammary cells.

Increments in $\alpha$-linolenic and oleic acids would represent a remarkable advantage of diets based on pasture from a nutritional point of view. Furthermore, a reduction in $\mathrm{C} 12: 0, \mathrm{C} 14: 0$, and $\mathrm{C} 16: 0$ contents resulted in a large decrease in the milk fat atherogenicity index in the pasture diet compared with the TMR (Table 4). Feeding pasture alone also brought about increases in other FA that are potentially beneficial to health. Milk fat from grazing ewes had $>50 \%$ more RA than milk fat from ewes on the TMR (Table 5). This positive effect of pasture intake on milk fat CLA content has been previously found, not only in dairy cows (Kelly et al., 1998) but also in dairy sheep and goats (Cabiddu et al., 2005; Tsiplakou et al., 2006). Nevertheless, when the pasture-based diet was supplemented with oat grain, the beneficial effect was not so clear. Although milk from PS ewes showed the highest concentration of $\mathrm{C} 18: 0$ and cis-9 $\mathrm{C} 18: 1$, oat grain (PS vs. pasture

Table 3. Milk unsaturated fatty acid profile ( $\mathrm{g} / 100 \mathrm{~g}$ of total fatty acid methyl esters) determined by gas chromatography for ewes fed pasture, pasture plus oat grain (PS), and a TMR

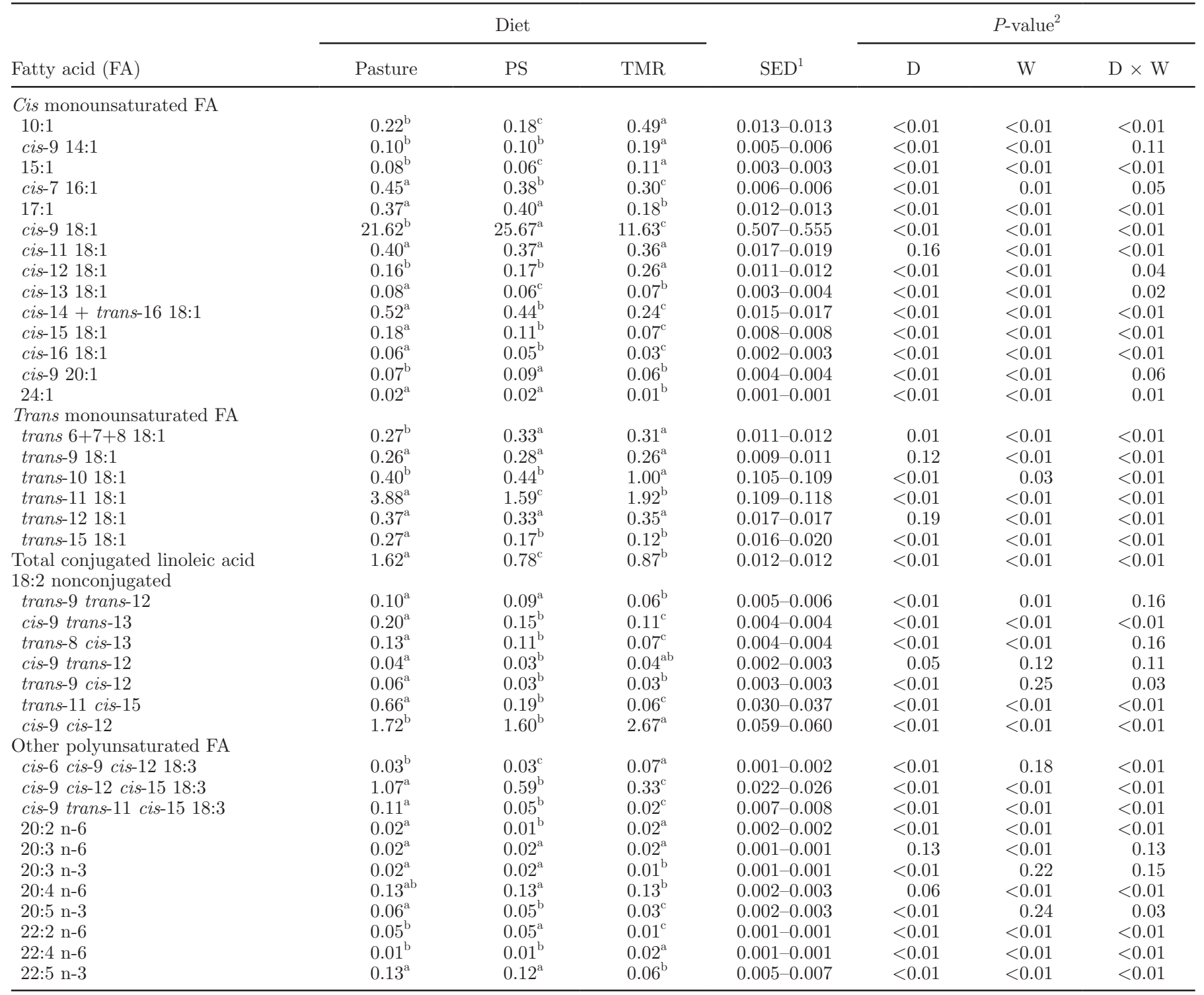

${ }^{\mathrm{a}-\mathrm{c}}$ Means within a row with different superscripts differ significantly.

${ }^{1} \mathrm{SED}=$ standard error of the difference. Depending on the treatment comparison (pasture vs. PS, pasture vs. TMR, or PS vs. TMR), the statistical analysis calculates a different SED; minimum and maximum SED are presented here.

${ }^{2}$ Probability of significant effects due to treatment $(D)$, experimental week $(W)$, and their interaction $(D \times W)$. 
Table 4. Milk saturated fatty acid profile ( $\mathrm{g} / 100 \mathrm{~g}$ of total fatty acid methyl esters) determined by gas chromatography for ewes fed pasture, pasture plus oat grain (PS), and a TMR

\begin{tabular}{|c|c|c|c|c|c|c|c|}
\hline \multirow[b]{2}{*}{ Fatty acid } & \multicolumn{3}{|c|}{ Diet } & \multirow[b]{2}{*}{$\mathrm{SED}^{1}$} & \multicolumn{3}{|c|}{$P$-value ${ }^{2}$} \\
\hline & Pasture & PS & TMR & & $\mathrm{D}$ & $\mathrm{W}$ & $\mathrm{D} \times \mathrm{W}$ \\
\hline $4: 0$ & $4.33^{\mathrm{ab}}$ & $4.46^{\mathrm{a}}$ & $4.20^{\mathrm{b}}$ & $0.074-0.075$ & 0.03 & $<0.01$ & 0.40 \\
\hline $6: 0$ & $2.83^{\mathrm{b}}$ & $2.52^{\mathrm{c}}$ & $3.79^{\mathrm{a}}$ & $0.048-0.051$ & $<0.01$ & $<0.01$ & $<0.01$ \\
\hline $8: 0$ & $2.31^{\mathrm{b}}$ & $1.87^{\mathrm{c}}$ & $3.77^{\mathrm{a}}$ & $0.085-0.091$ & $<0.01$ & $<0.01$ & $<0.01$ \\
\hline 10:0 & $5.89^{\mathrm{b}}$ & $4.62^{\mathrm{c}}$ & $11.94^{\mathrm{a}}$ & $0.240-0.280$ & $<0.01$ & $<0.01$ & $<0.01$ \\
\hline $12: 0$ & $2.99^{\mathrm{b}}$ & $2.62^{\mathrm{c}}$ & $6.59^{\mathrm{a}}$ & $0.104-0.119$ & $<0.01$ & 0.04 & $<0.01$ \\
\hline $13: 0$ iso & $0.02^{\mathrm{b}}$ & $0.02^{\mathrm{a}}$ & $0.01^{\mathrm{c}}$ & $0.001-0.001$ & $<0.01$ & $<0.01$ & 0.05 \\
\hline 13:0 anteiso & $0.03^{\mathrm{b}}$ & $0.03^{\mathrm{b}}$ & $0.06^{\mathrm{a}}$ & $0.002-0.002$ & $<0.01$ & $<0.01$ & 0.17 \\
\hline $13: 0$ & $0.11^{\mathrm{b}}$ & $0.09^{\mathrm{b}}$ & $0.23^{\mathrm{a}}$ & $0.006-0.006$ & $<0.01$ & 0.04 & $<0.01$ \\
\hline $14: 0$ iso & $0.11^{\mathrm{a}}$ & $0.12^{\mathrm{a}}$ & $0.10^{\mathrm{b}}$ & $0.004-0.004$ & $<0.01$ & 0.08 & 0.09 \\
\hline $14: 0$ & $8.20^{\mathrm{b}}$ & $7.88^{\mathrm{b}}$ & $11.56^{\mathrm{a}}$ & $0.197-0.202$ & $<0.01$ & $<0.01$ & $<0.01$ \\
\hline $15: 0$ iso & $0.15^{\mathrm{c}}$ & $0.28^{\mathrm{a}}$ & $0.24^{\mathrm{b}}$ & $0.008-0.008$ & $<0.01$ & $<0.01$ & $<0.01$ \\
\hline 15:0 anteiso & $0.40^{\mathrm{c}}$ & $0.45^{\mathrm{b}}$ & $0.51^{\mathrm{a}}$ & $0.014-0.017$ & $<0.01$ & $<0.01$ & $<0.01$ \\
\hline $15: 0$ & $0.99^{\mathrm{a}}$ & $0.89^{\mathrm{b}}$ & $0.95^{\mathrm{ab}}$ & $0.024-0.025$ & 0.04 & $<0.01$ & $<0.01$ \\
\hline $16: 0$ iso & $0.26^{\mathrm{b}}$ & $0.28^{\mathrm{b}}$ & $0.33^{\mathrm{a}}$ & $0.012-0.016$ & $<0.01$ & 0.14 & 0.46 \\
\hline $16: 0$ & $21.81^{\mathrm{c}}$ & $22.49^{\mathrm{b}}$ & $25.23^{\mathrm{a}}$ & $0.193-0.194$ & $<0.01$ & $<0.01$ & $<0.01$ \\
\hline $17: 0$ iso + trans-9 $16: 1$ & $0.69^{\mathrm{a}}$ & $0.55^{\mathrm{b}}$ & $0.42^{\mathrm{c}}$ & $0.017-0.018$ & $<0.01$ & $<0.01$ & $<0.01$ \\
\hline $17: 0$ anteiso + cis-9 $16: 1$ & $1.14^{\mathrm{a}}$ & $1.18^{\mathrm{a}}$ & $1.20^{\mathrm{a}}$ & $0.042-0.046$ & 0.44 & $<0.01$ & $<0.01$ \\
\hline $17: 0$ & $0.91^{\mathrm{a}}$ & $0.90^{\mathrm{a}}$ & $0.67^{\mathrm{b}}$ & $0.022-0.024$ & $<0.01$ & $<0.01$ & $<0.01$ \\
\hline $18: 0$ iso & $0.11^{\mathrm{a}}$ & $0.09^{\mathrm{b}}$ & $0.09^{\mathrm{b}}$ & $0.005-0.007$ & $<0.01$ & 0.02 & 0.10 \\
\hline $18: 0$ & $9.93^{\mathrm{b}}$ & $12.75^{\mathrm{a}}$ & $5.29^{\mathrm{c}}$ & $0.205-0.219$ & $<0.01$ & $<0.01$ & 0.06 \\
\hline $19: 0$ & $0.05^{\mathrm{a}}$ & $0.06^{\mathrm{a}}$ & $0.06^{\mathrm{a}}$ & $0.003-0.003$ & 0.24 & 0.04 & 0.09 \\
\hline $20: 0$ & $0.15^{\mathrm{b}}$ & $0.25^{\mathrm{a}}$ & $0.14^{\mathrm{c}}$ & $0.004-0.005$ & $<0.01$ & $<0.01$ & $<0.01$ \\
\hline $21: 0$ & $0.07^{\mathrm{a}}$ & $0.06^{\mathrm{b}}$ & $0.05^{\mathrm{c}}$ & $0.002-0.003$ & $<0.01$ & $<0.01$ & $<0.01$ \\
\hline $22: 0$ & $0.10^{\mathrm{a}}$ & $0.10^{\mathrm{a}}$ & $0.07^{\mathrm{b}}$ & $0.002-0.002$ & $<0.01$ & $<0.01$ & $<0.01$ \\
\hline $23: 0$ & $0.07^{\mathrm{a}}$ & $0.06^{\mathrm{b}}$ & $0.04^{\mathrm{c}}$ & $0.003-0.003$ & $<0.01$ & $<0.01$ & $<0.01$ \\
\hline $24: 0$ & $0.05^{\mathrm{a}}$ & $0.05^{\mathrm{a}}$ & $0.03^{\mathrm{b}}$ & $0.003-0.003$ & $<0.01$ & 0.02 & $<0.01$ \\
\hline $\mathrm{AI}^{3}$ & $1.53^{\mathrm{b}}$ & $1.54^{\mathrm{b}}$ & $3.22^{\mathrm{a}}$ & $0.068-0.071$ & $<0.01$ & 0.01 & 0.02 \\
\hline
\end{tabular}

${ }^{\mathrm{a}-\mathrm{c}}$ Means within a row with different superscripts differ significantly.

${ }^{1} \mathrm{SED}=$ standard error of the difference. Depending on the treatment comparison (pasture vs. PS, pasture vs. TMR, or PS vs. TMR), the statistical analysis calculates a different SED; minimum and maximum SED are presented here.

${ }^{2}$ Probability of significant effects due to treatment (D), experimental week $(\mathrm{W})$, and their interaction $(\mathrm{D} \times \mathrm{W})$.

${ }^{3} \mathrm{AI}=$ atherogenicity index $[(\mathrm{C} 12: 0+4 \times \mathrm{C} 14: 0+\mathrm{C} 16: 0) /(\mathrm{MUFA}+\mathrm{PUFA})] ;$ MUFA and PUFA $=$ mono- and polyunsaturated fatty acids.

Table 5. Conjugated linoleic acid (CLA) isomer profile of milk fat (mg/g of total fatty acids methyl esters) determined by silver-ion HPLC for ewes fed pasture, pasture plus oat grain (PS), and a TMR

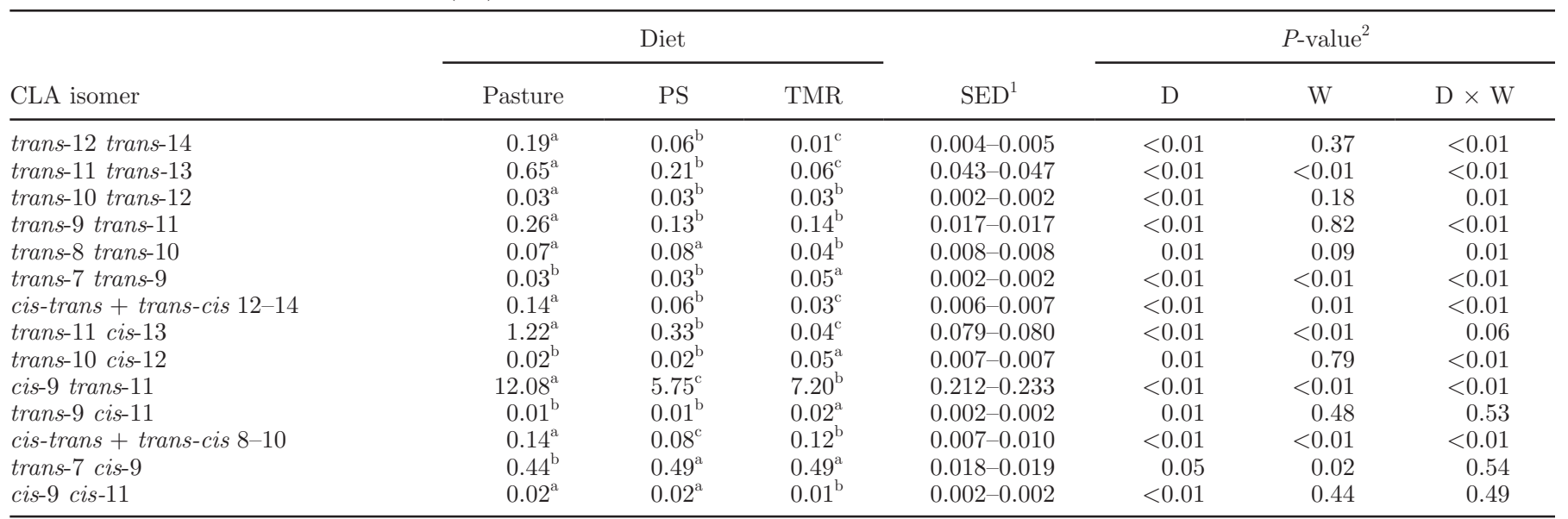

${ }^{\mathrm{a}-\mathrm{c}}$ Means within a row with different superscripts differ significantly.

${ }^{1} \mathrm{SED}=$ standard error of the difference. Depending on the treatment comparison (pasture vs. PS, pasture vs. TMR, or PS vs. TMR), the statistical analysis calculates a different SED; minimum and maximum SED are presented here.

${ }^{2}$ Probability of significant effects due to treatment (D), experimental week (W), and their interaction $(\mathrm{D} \times \mathrm{W})$. 
treatments) significantly reduced RA $(-53 \%)$ and VA $(-59 \%)$, the lowest levels observed in the trial (Tables $3,4$, and 5$)$.

These results suggest that supplementation with oat grain probably favored the major rumen PUFA biohydrogenation pathways (associated with modifications in the rumen bacterial populations), inducing a more complete hydrogenation of unsaturated FA presented in the diet. This argument is borne out by the presence of significantly $(P<0.01)$ smaller amounts of cis-9 trans-11 cis-15 C18:3 (CLnA, rumelenic acid) and trans-11 cis-15 C18:2 (PS vs. pasture), both intermediates in the biohydrogenation pathway of $\alpha$-linolenic acid. The lower VA content of the milks from PS animals would seem to be another indication of a greater activity of the ruminal microbiota responsible for the last stage of biohydrogenation of PUFA in the oat grain diet.

Compared with the PS diet, the pasture diet resulted in higher proportions of milk fat CLnA. Likewise, contents of trans-11 cis-15 C18:2 and VA (Table 3) were significantly higher in this treatment. This nonconjugated isomer of linoleic acid has been recognized as one of the products quantitatively most important in the biohydrogenation of CLnA in the digestive tract of ruminants (Loor et al., 2004) and is one of the most characteristic isomers of $\mathrm{C} 18: 2$ in diets rich in $\alpha$-linolenic acid (Collomb et al., 2004; Luna et al., 2005b; Akraim et al., 2007).

More recent studies have shown that the main pathway of biohydrogenation of $\alpha$-linolenic acid is more diverse than previously thought (Bessa et al., 2007; Chilliard et al., 2007). Among the wide range of intermediates formed in the rumen, cis-15 and trans-15 C18:1 represent putative pathways of hydrogenation from trans-11 cis-15 C18:2 as suggested by the increases observed in in vitro incubations of a source rich in $\alpha$-linolenic acid (Jouany et al., 2007) or in in vivo studies (Loor et al., 2005). In the present study (see Table 3 ), cis-15 and trans-15 C18:1 contents were significantly $(P<0.01)$ higher in the pasture treatment, which could be related to trans-11 cis- $15 \mathrm{C} 18: 2\left(\mathrm{R}^{2}=0.88\right.$ and 0.74 , respectively). The content of these monounsaturated FA in diets supplemented with oat grain was between that of the pasture and TMR treatments but closer to the latter. These data would support the idea expressed above that the inclusion of oat grain in the diet would favor the complete biohydrogenation of PUFA, with a consequent drop in the intermediates associated with such a process (see Tables 3 and 5 ).

The increased levels of cis-9 trans-13 C18:2 in the pasture treatment (Table 3) might result from alternative pathways of biohydrogenation of $\alpha$-linolenic acid other than CLnA. One potential pathway would be preceded by the formation of cis-9 trans-13 cis-15 C18:3 (Bessa et al., 2007). To the best of our knowledge, however, the presence of this biohydrogenation intermediate has not been reported in milk fat or rumen fluid. It would seem more likely that the increases in cis-9 trans-13 C18:2 are the product of the action of $\Delta^{9}$-desaturase of the mammary gland on the trans-13 C18:1 generated in the rumen. Although in the experimental conditions of this study, it was not possible to determine the trans-13 C18:1 content (this isomer elutes at the same peak as cis-9 C18:1), a close association between milk fat trans-13 and cis-9 trans-13 C18:2 content observed in a previous study (Roy et al., 2006) provided good evidence to suggest that a proportion of cis-9 trans-13 C18:2 secreted in milk is derived from endogenous conversion of trans-13 C18:1 via $\Delta^{9}$-desaturase in the mammary gland.

Feeding pasture alone was observed to increase the levels of trans-11 trans-13 and trans-11 cis-13 C18:2 in milk fat compared with feeding a TMR, with a lesser effect on the contents of trans-12 trans-14 and cis-12 trans-14 C18:2 (Figure 1), as previously reported in different ruminants fed on pasture (Kraft et al., 2003) or on diets with enhanced $\alpha$-linolenic acid content (Collomb et al., 2004; Luna et al., 2005b). Supplementation with oat grain also resulted in significantly higher levels of these isomers (see Table 5) compared with the TMR diet, but still much lower than those measured in the pasture treatment, which again reveals the effect of the inclusion of this supplement on the rumen bacterial communities that may favor a more appropriate ruminal environment for the complete biohydrogenation of $\alpha$-linolenic acid.

Hino and Fukuda (2006) presented data (obtained from an in vitro experiment) from new Butyrivibrio fibrisolvens strains, indicating that trans-11 cis-13 C18:2 is formed by isomerization of trans-11 cis-15 C18:2. Several other CLA isomers (trans-11 trans-13, trans-12 trans-14, and cis-12 trans-14 C18:2) clustered very closely to the former biohydrogenation of $\alpha$-linolenic acid in muscle FA in lambs (Bessa et al., 2007). Those isomers were associated with $\alpha$-linolenic acid ingestion. Bessa et al. (2007) postulated that cis-12 trans-14 CLA found in lamb meat samples could be formed from $\alpha$-linolenic acid via cis-12 cis-15 C18:2, but this intermediate was not detected in the current research and the putative pathways for its presence in milk fat are far from clear.

The PS treatment did not, however, modify CLA content of other isomers such as trans-10 cis-12 or trans- 9 cis-11 (Table 5), which may be because these intermediates come basically from diets with a high proportion of concentrate and rich in linoleic acid (Gómez-Cortés et al., 2008). Likewise, the trans-10 C18:1 content, generally associated with the biohydrogenation of linoleic 


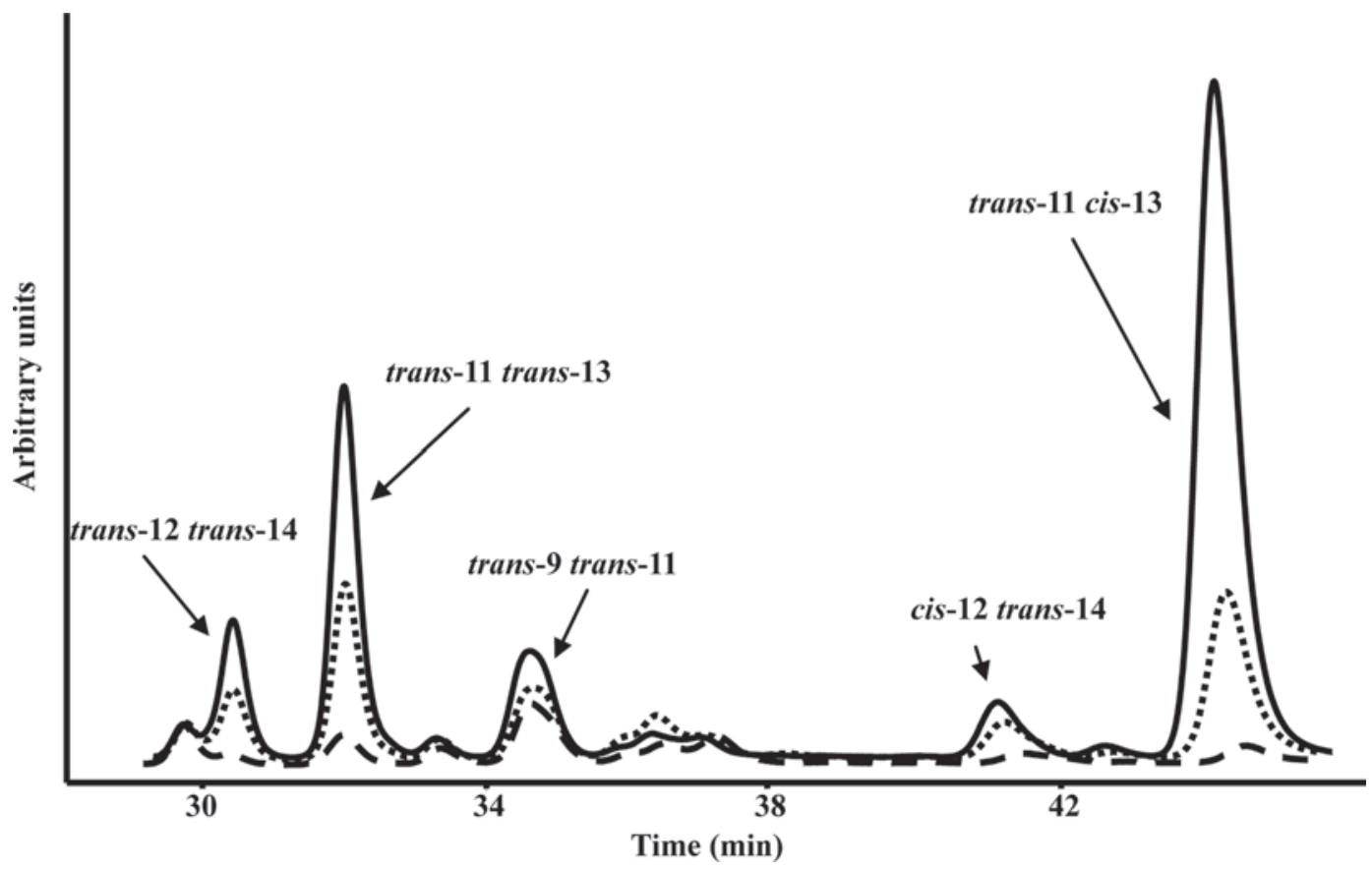

Figure 1. Partial silver-ion HPLC chromatograms of milk fat from ewes fed pasture (-), pasture plus oat grain (....), or a TMR $(---)$.

acid via trans-10 cis-12 CLA, did not differ between the pasture and PS diets, in both of which trans-10 C18:1 was significantly $(P<0.01)$ lower than in the TMR diet.

\section{CONCLUSIONS}

Milk fat produced by ewes on pasture had a FA profile that consumers might find more favorable compared with that from ewes under intensive systems. However, traditional supplementation of grazing ewes with oat grain (treatment PS) favored complete ruminal biohydrogenation of PUFA and did not permit the maintenance of the desirable milk FA profile. Furthermore, it had no significant positive effect on milk production. Our results showed that the supplementation of grazing ewes with oat grain favored a more complete conversion of $\alpha$-linolenic acid to C18:0 (associated with changes in the rumen bacterial communities), whereas pasture alone generated higher levels of desirable intermediates (mainly VA and RA).

It is nevertheless noteworthy that this experiment was conducted when pasture quality and availability were good enough to maintain animal performance (in terms of milk yield and composition) and forage intake was most probably reduced because of feeding the cereal concentrate. Results would probably be different when pasture quality or availability limited dairy production, so further research under such conditions would be highly recommended.

\section{ACKNOWLEDGMENTS}

This work was supported by the Ministerio de Educación y Ciencia (AGL2005-04760). The authors from Instituto del Frío (Consejo Superior de Investigaciones Científicas, CSIC) thank Comunidad Autónoma de Madrid (S-505/AGR-0153) and the Ministerio de Educación y Ciencia (Consolider CSD2007-063) for the financial support. The authors from Instituto de Ganadería de Montaña (CSIC-Universidad de León) thank CSIC (200640I212) for the financial support. The authors thank J. López and O. López-Campos (Instituto de Ganadería de Montaña, León, Spain) and M. V. Rodríguez-Pino (Instituto del Frío, Madrid, Spain) for their skilled technical assistance.

\section{REFERENCES}

Addis, M., A. Cabiddu, G. Pinna, M. Decandia, G. Piredda, A. Pirisi, and G. Molle. 2005. Milk and cheese acid composition in sheep fed Mediterranean forages with reference to conjugated linoleic acid cis-9 trans-11. J. Dairy Sci. 88:3443-3454.

Akraim, F., M. C. Nicot, P. Juaneda, and F. Enjalbert. 2007. Conjugated linolenic acid (CLnA), conjugated linoleic acid (CLA) and other biohydrogenation intermediates in plasma and milk fat cows fed raw or extruded linseed. Animal 1:835-843.

AOAC. 2006. Official Methods of Analysis of the Association of Official Agricultural Chemists. 18th ed. 1st rev. AOAC Int., Gaithersburg, MD.

AOCS. 2008. Official Methods and Recommended Practices of the American Oil Chemist's Society (Official Procedure Am 5-04). 5th Edn. (2nd printing). AOCS, Urbana, IL.

Bargo, F., L. D. Muller, E. S. Kolver, and J. E. Delahoy. 2003. Invited review: Production and digestion of supplemented dairy cows on pasture. J. Dairy Sci. 86:1-42. 
Barthram, G. T. 1986. Experimental techniques: The HFRO swardstick. Pages 249-279 in The Hill Farming Research Organisation Biennial Report 1984-85. Hill Farming Research Organisation, Bush Estate, Penicuik, Midlothian, UK.

Bessa, R. J. B., S. P. Alves, E. Jerónimo, C. A. Alfaia, J. A. M. Prates, and J. Santos-Silva. 2007. Effect of lipid supplements on ruminal biohydrogenation intermediates and muscle fatty acids in lambs. Eur. J. Lipid Sci. Technol. 109:868-878.

Bocquier, F., M. Theriez, S. Prache, and A. Brelurut. 1988. Alimentation des ovins. Pages 249-279 in Alimentation des Bovins, Ovins \& Caprins. R. Jarrige, ed. INRA Publ., Paris, France.

Cabiddu, A., M. Addis, G. Pinna, S. Spada, M. Fiori, M. Sitzia, A. Pirisi, G. Piredda, and G. Molle. 2006. The inclusion of a daisy plant (Chrysanthemum coronarium) in dairy sheep diet. 1: Effect on milk and cheese fatty acid composition with particular reference to C18:2 cis-9 trans-11. Livest. Sci. 101:57-67.

Cabiddu, A., M. Decandia, M. Addis, G. Piredda, A. Pirisi, and G. Molle. 2005. Managing Mediterranean pastures in order to enhance the level of beneficial fatty acids in sheep milk. Small Rumin. Res. 59:169-180.

Chilliard, Y., F. Glasser, A. Ferlay, L. Bernard, J. Rouel, and M. Doreau. 2007. Diet, rumen biohydrogenation and nutritional quality of cow and goat milk fat. Eur. J. Lipid Sci. Technol. 109:828-855.

Collomb, M., R. Sieber, and U. Bütikofer. 2004. CLA isomers in milk fat from cows fed diets with high levels of unsaturated fatty acids. Lipids 39:355-364.

Gómez-Cortés, P., P. Frutos, A. R. Mantecón, M. Juárez, M. A. de la Fuente, and G. Hervás. 2008. Milk production, CLA content and in vitro ruminal fermentation in response to high levels of soybean oil in dairy ewe diet. J. Dairy Sci. 91:1560-1569.

Hino, T., and S. Fukuda. 2006. Biohydrogenation of linoleic and linolenic acids, and production of their conjugated isomers by Butyrivibrio fibrisolvens. 4th Euro Fed Lipid Congress, Madrid, Spain.

ISO. 1999a. ISO 6496: Animal feeding stuffs - Determination of moisture and other volatile matter content. International Organization for Standardization, Geneva, Switzerland.

ISO. 1999b. ISO 9622: Whole milk-Determination of milk fat, protein and lactose content. International Organization for Standardization, Geneva, Switzerland.

ISO. 2002a. ISO 5984: Animal feeding stuffs-Determination of crude ash. International Organization for Standardization, Geneva, Switzerland.

ISO. 2002b. ISO 15884: Milk fat-Preparation of fatty acid methyl esters. International Organization for Standardization, Geneva, Switzerland.

ISO. 2005. ISO 5983-2: Animal feeding stuffs - Determination of nitrogen content and calculation of crude protein content Part 2: Block digestion/steam distillation method. International Organization for Standardization, Geneva, Switzerland.

Jouany, J. P., B. Lassalas, M. Doreau, and F. Glasser. 2007. Dynamic features of the rumen metabolism of linoleic acid, linolenic acid and linseed oil measured in vitro. Lipids 42:351-360.

Kelly, M. L., E. S. Kolver, D. E. Bauman, M. E. Van Amburgh, and L. D. Muller. 1998. Effect of intake of pasture on concentrations as CLA in milk of lactating cows. J. Dairy Sci. 81:1630-1636.
Kraft, J., M. Collomb, P. Möckel, R. Sieber, and G. Jahreis. 2003 Differences in CLA isomer distribution of cow's milk lipids. Lipids 38:657-664.

Lock, A. L., B. M. Teles, J. W. Perfield II, D. E. Bauman, and L. A. Sinclair. 2006. A conjugated linoleic acid supplement containing trans-10, cis-12 reduces milk fat synthesis in lactating sheep. J. Dairy Sci. 89:1525-1532.

Loor, J. J., A. Ferlay, A. Ollier, K. Ueda, M. Doreau, and Y. Chilliard. 2005. High-concentrate diets and polyunsaturated oils alter trans and conjugated isomers in bovine rumen, blood, and milk. J. Dairy Sci. 88:3986-3999.

Loor, J. J., K. Ueda, A. Ferlay, Y. Chilliard, and M. Doreau. 2004. Biohydrogenation, duodenal flow, and intestinal digestibility of trans fatty acids and conjugated linoleic acids in response to dietary forage:concentrate ratio and linseed oil in dairy cows. J. Dairy Sci. 87:2472-2485.

Luna, P., J. Fontecha, M. Juárez, and M. A. de la Fuente. 2005b. Changes in the milk and cheese fat composition of ewes fed commercial supplements containing linseed with special reference to the CLA content and isomer composition. Lipids 40:445-454.

Luna, P., M. Juárez, and M. A. de la Fuente. 2005a. Validation of a rapid milk fat separation method to determine the fatty acid profile by gas chromatography. J. Dairy Sci. 88:3377-3381.

Mel'uchová, B., J. Blaško, R. Kubinec, R. Górová, J. Dubravská, M. Margetín, and L. Soják. 2008. Seasonal variations in fatty acid composition of pasture forage plants and CLA content in ewe milk fat. Small Rumin. Res. 78:56-65.

Mertens, D. R. 2002. Gravimetric determination of amylase-treated neutral detergent fiber in feeds with refluxing in beakers or crucibles: Collaborative study. J. AOAC Int. 85:1217-1240.

Molle, G., M. Decandia, A. Cabiddu, S. Y. Landau, and A. Cannas. 2008. An update on the nutrition of dairy sheep grazing Mediterranean pastures. Small Rumin. Res. 77:93-112.

Molle, G., S. Ligios, N. Fois, M. Decandia, S. Casu, and G. Bomboi 1997. Response by dairy ewes to different sward heights under continuous stocking either unsupplemented or supplemented with corn grain. Options Méditerranéennes Série A 34:65-70.

Morand-Fehr, P., V. Fedele, M. Decandia, and Y. Le Frileux. 2007. Influence of farming and feeding systems on composition and quality of goat and sheep milk. Small Rumin. Res. 68:20-34.

Orskov, E. R., C. Fraser, and J. G. Gordon. 1974. Effect of processing of cereals on rumen fermentation, digestibility, rumination time, and firmness of subcutaneous fat in lambs. Br. J. Nutr. 32:5969.

Pulina, G., A. Nudda, G. Battacone, and A. Cannas. 2006. Effects of nutrition on the contents of fat, protein, somatic cells, aromatic compounds, and undesirable substances in sheep milk. Anim. Feed Sci. Technol. 131:255-291.

Roy, A., A. Ferlay, K. J. Shingfield, and Y. Chilliard. 2006. Examination of the persistency of milk fatty acid composition responses to plant oils in cows given different basal diets, with particular emphasis on trans-C18:1 fatty acids and isomers of conjugated linoleic acid. Anim. Sci. 82:479-492.

Tsiplakou, E., K. C. Mountzouris, and G. Zervas. 2006. Concentration of conjugated linoleic acid in grazing sheep and goat milk fat. Livest. Sci. 103:74-84. 